\title{
A Novel Poly(vinyl chloride) Matrix Membrane Sensor for Batch and Flow-Injection Determinations of Thiocyanate, Cyanide and Some Metal Ions
}

\author{
Saad S. M. Hassan, ${ }^{\dagger}$ Ibrahim H. A. BAdr, Ayman H. Kamel, and Mona S. Mohamed \\ Department of Chemistry, Faculty of Science, Ain Shams University, Cairo, Egypt
}

\begin{abstract}
A poly(vinyl chloride) matrix membrane sensor for the selective determination of thiocyanate has been developed based on the use of copper(II)-2-(5-bromo-2-pyridylazo)-5-diethylaminophenol complex (Cu-PADAP) as a novel charged carrier, and $o$-nitrophenyloctyl ether (o-NPOE) as a solvent mediator. The sensor displays a significantly enhanced response towards $\mathrm{SCN}^{-}$ions over the concentration range $7.0 \times 10^{-6}$ to $1.0 \times 10^{-2} \mathrm{~mol} \mathrm{~L}^{-1}$ with a detection limit of $5.6 \times$ $10^{-6} \mathrm{~mol} \mathrm{~L}^{-1}$ and a calibration slope of $-57.5 \pm 0.5 \mathrm{mV}$ decade $^{-1}$. The sensor exhibits a long life-span, long-term stability, high reproducibility, and a fast response time. The selectivity coefficients of some anions were calculated using the separate solutions method, and found to be in the following order: $\mathrm{SCN}^{-}>\mathrm{ClO}_{4}^{-}>\mathrm{I}^{-}>\mathrm{Sal}^{-}>\mathrm{NO}_{2}^{-}>\mathrm{Br}^{-}>\mathrm{NO}_{3}^{-}=$ $\mathrm{CH}_{3} \mathrm{COO}^{-}>\mathrm{Cl}^{-}>\mathrm{SO}_{4}{ }^{2-}=\mathrm{PO}_{4}{ }^{3-}$. The effects of the $\mathrm{pH}$ and ionic membrane additives (e.g. tridodecylmethylammonium chloride, TDMAC and potassium tetrakis[bis(3,5-trifluoromethyl)phenyl] borate, KTFPB) were examined. The sensor was used for the determination of $\mathrm{SCN}^{-}$ions in saliva and urine samples collected from some smoker and non-smoker donors. The developed sensor was also applied to determine the cyanide content in electroplating waste water samples after its conversion into thiocyanate. The application of the sensor to monitor the potentiometric titration of $\mathrm{Ag}^{+}$and $\mathrm{Hg}^{2+}$ using $\mathrm{SCN}^{-}$resulted in sharp inflection breaks at the equivalent points. The data obtained using the proposed sensor correlate very well with results collected using the standard methods of thiocyanate, cyanide and metal analysis.
\end{abstract}

(Received August 14, 2008; Accepted December 24, 2008; Published July 10, 2009)

\section{Introduction}

The thiocyanate anion possesses numerous industrial and biological applications, and is a potent inhibitor of iodide transport in humans. ${ }^{1}$ Thiocyanate is also the end product of the detoxification of cyanide compounds, and is excreted in urine, saliva and sweat. The thiocyanate content in human saliva is considered to be a biomarker for the identification of nonsmokers and smokers. Human plasma levels are 2-3 $\mathrm{mg} \mathrm{L}^{-1}$ in nonsmokers and $9-12 \mathrm{mg} \mathrm{L}^{-1}$ in smokers. ${ }^{2}$ Chronically elevated levels of thiocyanate in body fluids are known to be toxic and correlate with local goiter, vertigo, and unconsciousness. ${ }^{3}$ On the other hand, thiocyanate containing waste discharged into rivers is harmful to aquatic life due to its degradation to cyanide in the presence of oxidants. Therefore, a simple, rapid, reproducible, and high-throughput determination of the $\mathrm{SCN}^{-}$ concentration at low levels in body fluids, water and diverse industrial samples is highly demanded. Various methods, such as spectrometry, ${ }^{4}$ spectrofluorometry, ${ }^{5}$ Raman spectroscopy, ${ }^{6}$ capillary zone electrophoresis, ${ }^{7}$ gas chromatography, ${ }^{8}$ ion chromatography, ${ }^{9} \quad$ photokinetic voltammetry, ${ }^{10}$ and amperometry ${ }^{11}$ have been reported for thiocyanate determination. Most of these methods are time consuming and involve the use of sophisticated high-cost equipment.

Potentiometric sensors offer simple, cost effective, selective

† To whom correspondence should be addressed.

E-mail: saadsmhassan@yahoo.com and sensitive techniques for chemical analysis. Anion-selective membrane sensors based on the use of ion exchangers such as lipophilic quaternary ammonium or phosphonium salts, display the classical Hofmeister selectivity sequence: $\left(\mathrm{ClO}_{4}^{-}>\mathrm{SCN}^{-}>\right.$ $\left.\mathrm{I}^{-}>\mathrm{NO}_{3}{ }^{-}>\mathrm{Br}^{-}>\mathrm{NO}_{2}^{-}>\mathrm{Cl}^{-}>\mathrm{SO}_{4}{ }^{2-}\right)$. In this case the membrane selectivity is controlled only by the free energy of ion hydration $^{12,13}$ and the sensors respond more to highly lipophilic anion. Polymer membrane sensors incorporating lipophilic organo-metallic compounds or metal-ligand complexes show potentiometric selectivity patterns that deviate significantly from the Hofmeister sequence. ${ }^{14-18}$ Various anion carriers have been reported for the development of thiocyanate membrane sensors, including organo silver, ${ }^{19}$ nickel, ${ }^{20}$ copper, ${ }^{21}$ mercury,,${ }^{22}$ zinc, ${ }^{23}$ cadmium, ${ }^{24}$ manganese, ${ }^{25}$ and palladium ${ }^{26}$ complexes. Metal porphyrin, ${ }^{27}$ metallophthalocyanine, ${ }^{28}$ metal azamacrocyclic, ${ }^{29}$ and calixarene ${ }^{30}$ derivatives have also been used. Some of these sensors suffer from the disadvantages of poor selectivity, limited range of the linear response, and a long response time.

Herein, we present a novel potentiometric thiocyanate membrane sensor based on the $\mathrm{Cu}$ (II)-2-(5-bromo-2-pyridylazo)5-diethylaminophenol complex as a charged carrier. The selectivity behavior, response mechanism, response time, and signal stability were evaluated, and found to be superior than most of those previously described. The sensor is satisfactorily used for batch and flow-injection analysis of thiocyanate in biological fluids. The sensor is also utilized for the determination of cyanide in waste-water samples after conversion into thiocyanate. Potentiometric titrations of some metal ions with $\mathrm{SCN}^{-}$are successfully followed using the proposed sensor. 


\section{Experimental}

\section{Equipment}

All potential measurements were made at $25 \pm 1{ }^{\circ} \mathrm{C}$ with an Orion (Cambridge, MA) Model 720/SA pH/mV meter using the proposed thiocyanate membrane sensor in conjunction with an Orion $\mathrm{Ag} / \mathrm{AgCl}$ double-junction reference electrode (Model 90-20) filled with $10 \%(\mathrm{w} / \mathrm{v}) \mathrm{KNO}_{3}$. A combination Ross glass electrode (Orion 81-02) was used for $\mathrm{pH}$ measurements. A computer-controlled spectrophotometer (Jenway, Model 1601) was used for spectrophotometric measurements.

A flow-injection manifold utilized for the analysis of $\mathrm{SCN}^{-}$ consisted of a two-channel peristaltic pump (Ismatech Ms-REGLO), polyethylene tubing (0.71 $\mathrm{mm}$ i.d.), and an Omnifit injection valve (Omnifit, Cambridge, UK) with a sample loop of $100 \mu \mathrm{L}$ volume. The potential signals were recorded using a home-made high input-impedance 8-channel box connected to a PC through the interface ADC 16 (Pico Tech, UK) and Pico Log software (Ver. 5.07).

\section{Reagents}

2-[5-Bromo-2-pyridylazo-5-diethylaminophenol] (Br-PADAP), tridodecylmethylammonium chloride (TDMAC), potassium tetrakis[bis(3,5-trifluoromethyl)phenyl] borate (KTFPB), high molecular weight poly(vinyl chloride) (PVC), and $o$-nitrophenyloctyl ether $(o$-NPOE) were used as received from Fluka (Ronkonoma, NY). Tetrahydrofuran (THF) and 2-morpholinoethanesulfonic acid (MES) were purchased from Sigma (St. Louis, MO). The buffer used in this work was $0.05 \mathrm{~mol} \mathrm{~L}^{-1}$ MES buffer of $\mathrm{pH} 5$.

\section{Preparation of $\mathrm{Cu}$-PADAP complex}

$\mathrm{Cu}-\mathrm{PADAP}$ ionophore (Fig. 1) was prepared and structurally characterized using elemental analysis and spectral data according to literature procedures. ${ }^{31}$ To a solution containing 2-[5-bromo-2-pyridylazo-5-diethylaminophenol] (5-Br-PADAP) $(1.7 \mathrm{mmol})$ in $20 \mathrm{~mL}$ of ethyl alcohol, $\mathrm{CuSO}_{4} \cdot 5 \mathrm{H}_{2} \mathrm{O}(2.4 \mathrm{mmol})$ was added. A solid precipitate was immediately produced, stirred at room temperature for $30 \mathrm{~min}$, collected by filtration and washed with deionized water. The crude precipitate was recrystallized from ethanol to give fine violet crystals.

\section{Membrane preparation and EMF measurements}

Thiocyanate PVC membrane sensors were prepared as described previously. ${ }^{32,33}$ A $2-\mathrm{mg}$ portion of $\mathrm{Cu}$-PADAP complex was thoroughly mixed with $126 \mathrm{mg}$ of $o$-NPOE, $67 \mathrm{mg}$ of PVC and $3 \mathrm{~mL}$ of THF in a glass Petri dish ( $3 \mathrm{~cm}$ diameter) covered with a filter paper and left to stand overnight to allow slow evaporation of THF at room temperature. The master membrane was sectioned with a cork borer $(10 \mathrm{~mm}$ diameter $)$ and glued to PVC tubing ( $\sim 3 \mathrm{~cm}$ length; $8 \mathrm{~mm}$ i.d.) using THF. The sensor body consisted of a 5-ml pipette tip attached to PVC tubing. The internal reference solution was a mixture of equal volumes of $1.0 \times 10^{-2} \mathrm{~mol} \mathrm{~L}^{-1} \mathrm{KSCN}$ and $1.0 \times 10^{-2} \mathrm{~mol} \mathrm{~L}^{-1}$ KCl. $\mathrm{Ag} / \mathrm{AgCl}$ wire $(1.0 \mathrm{~mm}$ diameter $)$ was immersed in an internal reference solution. The sensor was conditioned by soaking in a $1.0 \times 10^{-2} \mathrm{~mol} \mathrm{L^{-1 }}$ aqueous $\mathrm{KSCN}$ solution overnight, and was stored in the same solution when not in use. The sensor was calibrated under a static mode of operation by transferring $1.0 \mathrm{~mL}$ aliquots of a $1.0 \times 10^{-2}-1.0 \times 10^{-6} \mathrm{~mol} \mathrm{~L}^{-1}$ aqueous solution of $\mathrm{SCN}^{-}$to a $20-\mathrm{mL}$ beaker containing $9.0 \mathrm{~mL}$ of $0.05 \mathrm{~mol} \mathrm{~L}^{-1} \mathrm{MES}$ buffer of $\mathrm{pH}$. The sensor was immersed in the buffer solution in conjunction with a double-junction $\mathrm{Ag} / \mathrm{AgCl}$ reference electrode. The potential readings were

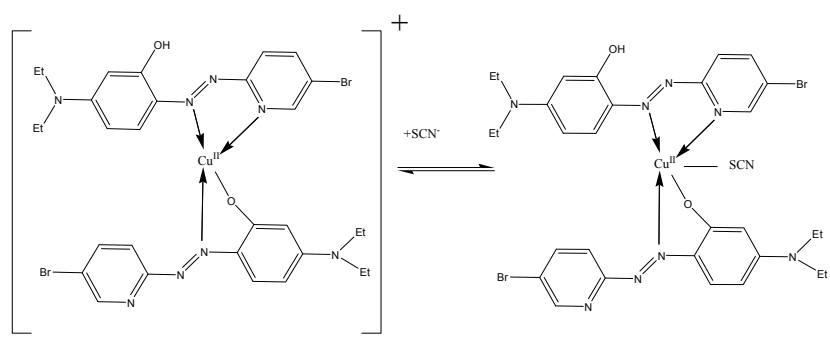

Fig. 1 Chemical structures of the $\mathrm{Cu}-\mathrm{PADAP}$ complex.

recorded after stabilization to $\pm 1 \mathrm{mV}$ and the emf was plotted as a function of the logarithm $\left[\mathrm{SCN}^{-}\right]$concentration.

\section{Flow-injection setup}

Tubular sensors were constructed according to literature procedures. $^{34}$ A casting membrane solution of the sensor was prepared by dissolving $67 \mathrm{mg}$ of PVC in $3 \mathrm{~mL}$ of THF, followed by the addition of $126 \mathrm{mg}$ of $o$-NPOE and $2 \mathrm{mg}$ of Cu-PADAP complex. The casting solution was deposited, using a micro dropper, onto a hole ( $3 \mathrm{~mm}$ wide $\times 5 \mathrm{~mm}$ length) made in the middle of a 5-cm Tygon tube (ALKEM, P/N A003494). The casting process was repeated 3 times at 2 min intervals. The tube was inserted and sealed with Araldite into a pipette tip. The tubular sensor was inserted into the flow-injection system and $0.05 \mathrm{~mol} \mathrm{~L}^{-1}$ MES buffer of $\mathrm{pH} 5$ was used as a carrier solution at a flow rate of $3 \mathrm{~mL} \mathrm{~min}{ }^{-1}$. The tubular sensor was located at a distance of about $30 \mathrm{~cm}$ from the injection valve and at a distance of about $20 \mathrm{~cm}$ from the waste container. An Orion $\mathrm{Ag} / \mathrm{AgCl}$ double-junction reference electrode was placed in the waste reservoir downstream from the working sensor. The detector was calibrated at $25^{\circ} \mathrm{C}$ by the injection of thiocyanate samples through a loop of $100 \mu \mathrm{L}$ volume in the carrier stream.

\section{Determination of $\mathrm{SCN}^{-}$in saliva and urine}

Samples of saliva and urine were collected from cigarette smokers (10 persons each) and non-smokers into polyethylene tubes. The samples were immediately centrifuged and stored at $4^{\circ} \mathrm{C}$. A $1.0-\mathrm{mL}$ aliquot of the sample was transferred into a $10-\mathrm{mL}$ measuring flask and diluted with $0.05 \mathrm{~mol} \mathrm{~L}^{-1} \mathrm{MES}$ buffer of $\mathrm{pH}$ 5. For batch analysis, the thiocyanate sensor and double-junction $\mathrm{Ag} / \mathrm{AgCl}$ reference electrode were immersed in the same solution, and the potential readings were recorded.

For flow-injection analysis (FIA), successive $100 \mu \mathrm{L}$ aliquots of the standard $\mathrm{SCN}^{-}$solution and the unknown thiocyanate test samples were injected into a flowing stream of $0.05 \mathrm{~mol} \mathrm{~L}^{-1}$ MES buffer of $\mathrm{pH} 5$. A typical FIA calibration plot was made by plotting the potential change against the logarithm $\left[\mathrm{SCN}^{-}\right]$ concentration. The obtained calibration curve was used for subsequent determinations of $\mathrm{SCN}^{-}$in unknown samples.

\section{Potentiometric determination of cyanide}

An aliquot of $5 \mathrm{~mL}$ of standard $1.0 \times 10^{-6}$ to $1.0 \times 10^{-2} \mathrm{~mol} \mathrm{~L}^{-1}$ $\mathrm{CN}^{-}$test solutions was successively added to $20 \mathrm{~mL}$ beakers containing $5 \mathrm{ml}$ aliquots of $1.0 \times 10^{-6}$ to $1.0 \times 10^{-2} \mathrm{~mol} \mathrm{~L}^{-1}$ ammonium polysulfide. The solution was boiled for $15 \mathrm{~min}$ using a hot plate, cooled and transferred into a $10-\mathrm{mL}$ measuring flask and completed to the mark with $0.05 \mathrm{~mol} \mathrm{~L}^{-1}$ MES buffer of $\mathrm{pH} 5$. The solution was shaken well and transferred to a $100-\mathrm{mL}$ beaker. A thiocyanate sensor in conjunction with a 
double-junction $\mathrm{Ag} / \mathrm{AgCl}$ reference electrode was immersed into the test solution. The potential changes after each addition were recorded, and a calibration curve was constructed by plotting the potential reading against the logarithm of the cyanide concentration.

\section{Results and Discussion}

Potentiometric characteristics of thiocyanate membrane sensors The reaction of copper(II) with 5-Br-PADAP in an acidic medium of $\mathrm{pH} 3.2$ gave a charged complex $^{31,35}$ with the composition $[\mathrm{Cu}(\mathrm{II}) \mathrm{R}(\mathrm{R}-\mathrm{H})]^{+}$(Fig. 1). The complex was prepared, characterized, dispersed in a plasticized polymeric membrane and used as a potentiometric sensor for thiocyanate. A conventional poly(vinyl chloride) matrix membrane sensor based on the Cu-PADAP complex as an ionophore and plasticized with $o$-nitrophenyloctyl ether (NPOE) was prepared and tested under static- and flow-injection modes of operation (FIA). The composition of the membrane was $64.6 \mathrm{wt} \%$ plasticizer, $1.0 \mathrm{wt} \% \mathrm{Cu}-\mathrm{PADAP}$ complex, and $34.4 \mathrm{wt} \% \mathrm{PVC}$.

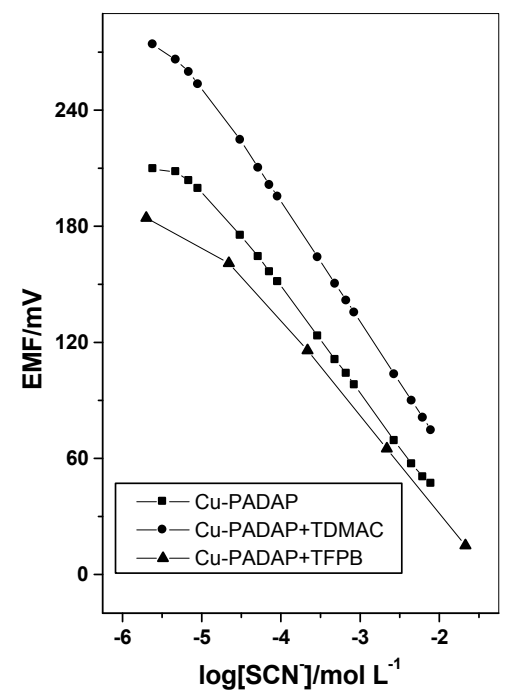

Fig. 2 Potentiometric response of Cu-PADAP ( $\square$ ), Cu-PADAP + TDMAC $(\mathbf{O})$, and Cu-PADAP + TFPB $(\boldsymbol{\Delta})$ based membrane sensors toward $\mathrm{SCN}^{-}$in a $0.05 \mathrm{~mol} \mathrm{~L}^{-1} \mathrm{MES}$ buffer, $\mathrm{pH} 5$.
At $\mathrm{pH} 5$, the sensor displayed a linear response toward $\mathrm{SCN}^{-}$ over the concentration range $7.0 \times 10^{-6}$ to $1.0 \times 10^{-2} \mathrm{~mol} \mathrm{~L}^{-1}$, a detection limit of $5.6 \times 10^{-6} \mathrm{~mol} \mathrm{~L}^{-1}$, and a near-Nernstian potentiometric response of $-57.5 \pm 0.5 \mathrm{mV}$ decade $^{-1}$ of thiocyanate (Fig. 2).

A Cu-PADAP based sensor with a membrane containing cationic additive (i.e. $30 \mathrm{~mol} \%$ TDMAC relative to the ionophore) showed an enhancement of the potentiometric response characteristics. This membrane electrode exhibited a slope of $-61.1 \pm 0.8 \mathrm{mV}$ decade $^{-1}$, a linear dynamic range of 5.6 $\times 10^{-6}$ to $1.0 \times 10^{-2} \mathrm{~mol} \mathrm{~L}^{-1}$, and a detection limit of $3.1 \times$ $10^{-6} \mathrm{~mol} \mathrm{~L}^{-1}$. Surprisingly, the incorporation of an anionic additive (i.e. $30 \mathrm{~mol}^{\%} \mathrm{TFPB}^{-}$relative to the ionophore) in the membrane of a $\mathrm{Cu}$-PADAP based sensor deteriorated the potentiometric response. The calibration slope, detection limit and linear response range observed in this case were $-49.0 \pm$ $0.2 \mathrm{mV}$ decade ${ }^{-1}, 1.0 \times 10^{-5} \mathrm{~mol} \mathrm{~L}^{-1}$ and $3.0 \times 10^{-5}$ to $1.0 \times 10^{-2}$ mol $\mathrm{L}^{-1}$, respectively. The obtained results are given in Table 1.

The potentiometric selectivity coefficients $\left(K_{\mathrm{SCN}, \mathrm{J}}^{\text {pot }}\right)$ of thiocyanate sensors based on the Cu-PADAP complex in a PVC membrane plasticized with $o$-nitrophenyloctyl ether $(o$-NPOE) with and without anionic and cationic additives were evaluated using the separate solutions method, ${ }^{36,37}$ with EMF values measured in $0.1 \mathrm{M}$ salt solutions and theoretical slope values. Although, the calibration slopes of most interfering ions measured with anionic additive containing membranes were sub-Nernstian, the theoretical slope values were used instead for calculating their selectivity coefficients. The practical analytical selectivity was also illustrated graphically (Fig. 3). This normalization allows a comparison of the obtained selectivity data with those previously reported. This approach was recommended and similarly used with non-Nernstian responding anions. $^{38}$

The selectivity of a thiocyanate sensor based on the use of a plasticized membrane electrode containing only TDMAC as an ion-exchanger was also examined for a comparison. The response for all ions was Nernstian; the calculated potentiometric selectivity coefficients are summarized in Table 2. The selectivity coefficients of a $\mathrm{Cu}$-PADAP membrane sensor without membrane additives were in the order: $\mathrm{SCN}^{-}>\mathrm{ClO}_{4}{ }^{-}>$ $\mathrm{I}^{-}>\mathrm{Sal}^{-}>\mathrm{NO}_{2}{ }^{-}>\mathrm{Br}^{-}>\mathrm{NO}_{3}{ }^{-}=\mathrm{CH}_{3} \mathrm{COO}^{-}>\mathrm{Cl}^{-}>\mathrm{SO}_{4}{ }^{2-}=$ $\mathrm{PO}_{4}{ }^{3-}$. Membrane electrodes doped with anionic sites (e.g. KTFPB $30 \mathrm{~mol} \%$ ) exhibited almost the same selectivity order of membranes containing no additives with a slight improvement of the potentiometric selectivity towards the thiocyanate anion,

Table 1 Potentiometric response characteristics of thiocyanate PVC membrane sensors based on Cu-PADAP, with and without anionic and cationic additives

\begin{tabular}{lccc}
\hline \multicolumn{1}{c}{ Parameter } & Cu-PADAP & Cu-PADAP + 30 mol\% TDMAC & Cu-PADAP + 30 mol $\%$ TFPB \\
\hline Slope/mV decade ${ }^{-1 a}$ & $-57.5 \pm 0.5$ & $-61.1 \pm 0.8$ & $-49.0 \pm 0.2$ \\
Correlation coefficient, $r$ & -0.9994 & -0.9997 & -0.9996 \\
Intercept/mV & 66.8 & 52.9 & 66 \\
Linear range/mol L-1a & $7.0 \times 10^{-6}-1.0 \times 10^{-2}$ & $5.6 \times 10^{-6}-1.0 \times 10^{-2}$ & $3.0 \times 10^{-5}-1.0 \times 10^{-2}$ \\
Detection limit/mol L & $5.6 \times 10^{-6}$ & $3.1 \times 10^{-6}$ & $1.0 \times 10^{-5}$ \\
Working range $(\mathrm{pH})$ & $3.2-8$ & $3-8.5$ & 5.0 \\
Response time/s & $<10$ & $<10$ & $<10$ \\
Precision, $\%$ & 1.1 & 0.8 & 1.2 \\
Accuracy, $\%$ & 0.5 & 1.2 & 0.6 \\
Reproducibility/mV & 1.3 & 1.6 & 1.5 \\
Between-day-variability $\left(C_{\mathrm{v}_{\mathrm{b}}}, \%\right)$ & 0.9 & 0.7 & 1 \\
Relative standard deviation, $\%$ & 1.1 & 0.9 & 1.9 \\
\hline
\end{tabular}

a. Average of six determinations. 

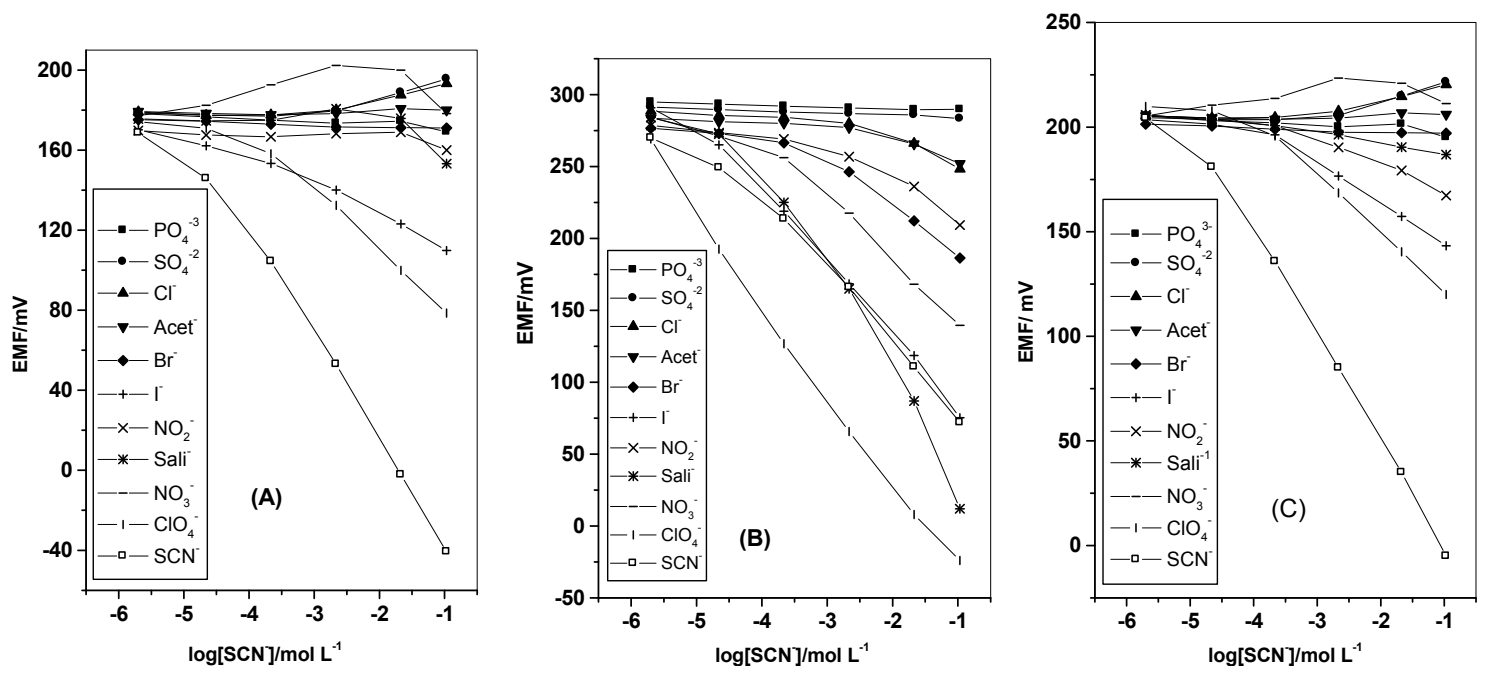

Fig. 3 Potential responses of: (A) Cu-PADAP based membrane sensor, (B) Cu-PADAP + TDMAC based membrane sensor, (C) Cu-PADAP + TFPB based membrane sensor towards varies anions: $-\mathrm{PO}_{4}{ }^{3-}(\boldsymbol{\square}) ;-\mathrm{SO}_{4}{ }^{2-}(\boldsymbol{\bullet}) ;-\mathrm{Cl}^{-}(\boldsymbol{\bullet})$; - acetate ${ }^{-}(\boldsymbol{\nabla}) ;-\mathrm{Br}^{-}(\bullet) ;-\mathrm{I}^{-}(+) ;-\mathrm{NO}_{2}^{-}(\mathrm{X})$; -salicylate (*); $-\mathrm{NO}_{3}{ }^{-}(-)$; $-\mathrm{ClO}_{4}^{-}(\mathrm{I}) ;-\mathrm{SCN}^{-}(\square)$.

Table 2 Selectivity coefficients $\left(K_{\mathrm{SCN}, \mathrm{I}}^{\mathrm{pot}}\right)$ of thiocyanate PVC membrane sensors based on Cu-PADAP, Cu-PADAP + TFPB, Cu-PADAP + TDMAC, and TDMAC

\begin{tabular}{|c|c|c|c|c|}
\hline \multirow[b]{2}{*}{$\begin{array}{c}\text { Interferant, } \\
\mathbf{J}\end{array}$} & \multicolumn{4}{|c|}{$\log K_{\mathrm{SCN}, J}^{\mathrm{pot}}$} \\
\hline & Cu-PADAP & $\begin{array}{c}\text { Cu-PADAP } \\
+30 \mathrm{~mol} \% \\
\text { TFPB }\end{array}$ & $\begin{array}{c}\text { Cu-PADAP } \\
+30 \text { mol } \% \\
\text { TDMAC }\end{array}$ & TDMAC \\
\hline $\mathrm{I}^{-}$ & $<-2.7$ & $<-2.9$ & -0.7 & 0 \\
\hline $\mathrm{NO}_{3}^{-}$ & $<-4.0$ & $<-4.3$ & -1.9 & -1.2 \\
\hline $\mathrm{NO}_{2}^{-}$ & $<-3.7$ & $<-3.4$ & $<-2.8$ & -2.6 \\
\hline $\mathrm{ClO}_{4}^{-}$ & $<-2.2$ & $<-2.7$ & 0.8 & +1.9 \\
\hline $\mathrm{Cl}^{-}$ & $<-4.2$ & $<-4.5$ & $<-3.9$ & -3.3 \\
\hline $\mathrm{PO}_{4}{ }^{3-}$ & $<-4.3$ & $<-4.5$ & $<-4.2$ & -3.9 \\
\hline $\mathrm{Br}^{-}$ & $<-3.8$ & $<-4.0$ & $<-2.8$ & -2.1 \\
\hline $\mathrm{CH}_{3} \mathrm{COO}^{-}$ & $<-4.0$ & $<-4.2$ & $<-3.9$ & -3.3 \\
\hline Salicylate $^{-}$ & $<-3.5$ & $<-3.8$ & +0.7 & +1.2 \\
\hline $\mathrm{SO}_{4}^{2-}$ & $<-4.3$ & $<-5.0$ & $<-4.2$ & -3.6 \\
\hline
\end{tabular}

a. $<$ Sign was used in the case of anions that did not respond in a Nernstian fashion.

compared with membrane sensors prepared without an anionic additive site. An improvement was obtained over perchlorate, iodide, nitrate, and bromide (i.e. the lipophilic anions), whereas no improvement was obtained over nitrite. This selectivity order clearly differs from the classical Hofmeister pattern. It is well known that PVC contains an anionic impurity that works well as a charged ionophore with small concentrations of ionic sites; similar effects were obtained with metalloporphyrins.

However, Cu-PADAP based membrane sensors doped with TDMAC as a cationic additive and membrane sensors incorporating only TDMAC displayed a selectivity pattern in the order: $\mathrm{ClO}_{4}^{-}>\mathrm{Sal}^{-}>\mathrm{SCN}^{-}>\mathrm{I}^{-}>\mathrm{NO}_{3}^{-}>\mathrm{NO}_{2}^{-}=\mathrm{Br}^{-}>$ $\mathrm{CH}_{3} \mathrm{COO}^{-}=\mathrm{Cl}^{-}>\mathrm{SO}_{4}^{2-}=\mathrm{PO}_{4}^{3-}$, which is almost identical to the Hofmeister pattern. The improvement of the potentiometric selectivity by the addition of anionic sites and the relative deterioration of the selectivity by the incorporation of cationic sites supports the charged-carrier mechanism of the Cu-PADAP ionophore. ${ }^{39,40}$ Membranes containing charged ionophores, but no ionic sites do exhibit anionic responses, but their selectivity can be improved by the use of anionic sites.

The observed selectivity behavior is due to the mode of interaction between the electroactive species in the membrane and the analyte anions in the aqueous test solution. For the classical ion-exchange membrane sensors (Cu-PADAP based membrane doped with TDMAC and that containing TDMAC only) where a Hofmeister pattern was displayed, the hydration energy or hydrophilicity of the anions plays a dominate role for the transfer of the anions across the organic/water membrane interface. However, membranes containing Cu-PADAP with/without TFPB exhibited a strong coordination affinity between the ionophore and some anions, leading to a non-Hofmeister selectivity sequence.

The effect of the $\mathrm{pH}$ on the response of the sensor was studied over the $\mathrm{pH}$ range of 2 to 11 at fixed concentrations of thiocyanate $\left(1.0 \times 10^{-4}\right.$ and $\left.1.0 \times 10^{-3} \mathrm{~mol} \mathrm{~L}^{-1}\right)$. The $\mathrm{pH}$ of these solutions was altered by adding $\mathrm{KOH}$ and/or $\mathrm{HCl}$. The potential response of the $\mathrm{Cu}$-PADAP membrane-based sensor was $\mathrm{pH}$ independent in the $\mathrm{pH}$ range $3.5-8$, as shown in Fig. 4. At approximately $\mathrm{pH}>8$, the potential decreased, probably due to an increase of the $\mathrm{OH}^{-}$competition with the $\mathrm{SCN}^{-}$anion.

The response time of the Cu-PADAP sensor was evaluated by measuring the time required to achieve a steady-state potential (within $\pm 0.2 \mathrm{mV}$ ). A response time of less than $10 \mathrm{~s}$ was obtained for all thiocyanate solutions in the linear calibration range. The stability and reproducibility of the response of the sensors were also tested. The potential readings remained constant for $\sim 10 \mathrm{~min}$ (drift $<0.5 \mathrm{mV}$ ). The potential readings of the sensor for 6 identical measurements over a period of 2 months showed variations of not more than $\pm 1.3 \mathrm{mV}$. The reproducibility of the calibration slope was within $\pm 1.5 \mathrm{mV}$ decade $^{-1}$ over a period of 2 months $(n=6)$.

A comparison of the selectivity coefficient values of the present sensor with some of those previously described is shown in Table 3. It can be seen that the present sensor offered better selectivity in the presence of $\mathrm{I}^{-}, \mathrm{NO}_{3}^{-}, \mathrm{NO}_{2}^{-}, \mathrm{Cl}^{-}$, and $\mathrm{Br}^{-},{ }^{20,21,24,28}$ as well as $\mathrm{ClO}_{4}{ }^{-},{ }^{20,21,24,28,29} \mathrm{SO}_{4}{ }^{2-},{ }^{20,23,24,28}$ and $\mathrm{PO}_{4}{ }^{3-}{ }^{21,23}$ The linear response range was slightly better than some of those previously suggested. ${ }^{19,33}$ 
Table 3 Selectivity coefficient data of some thiocyanate potentiometric membrane sensors

\begin{tabular}{|c|c|c|}
\hline Ionophore & Selectivity, $-\log K_{\mathrm{C} N \mathrm{~N}, \mathrm{~J}}^{\mathrm{pot}}$ & Ref. \\
\hline $\begin{array}{l}\text { 1,8-Dibenzyl-1,3,6,8,10,13- } \\
\text { hexaazacyclotetradecane-Ni(II)- } \\
\text { perchlorate }\end{array}$ & $\begin{array}{l}\mathrm{NO}_{2}^{-}, 2.04 ; \text { salicylate }{ }^{-}, 1.4 ; \mathrm{Br}^{-}, 1.6 ; \mathrm{SO}_{4}^{2-}, 1.3 ; \text { acetate } \\
2.3 ; 1.3 ; \mathrm{Cl}^{-}, 0.5\end{array}$ & 20 \\
\hline $\begin{array}{l}\text { Bis-[ } N \text {-(2-hydroxyethyl)salicylamino]- } \\
\text { copper(II) }\end{array}$ & $\begin{array}{l}\mathrm{ClO}_{4}^{-}, 1.9 ; \mathrm{I}^{-}, 2.3 ; \text { salicylate- }{ }^{-}, 2.4 ; \mathrm{Br}^{-}, 2.7 ; \mathrm{NO}_{2}^{-},-2.9 ; \mathrm{Cl}^{-}, 3.0 ; \mathrm{NO}_{3}^{-}, 3.2 ; \mathrm{H}_{2} \mathrm{PO}_{4^{-}} \text {, } \\
\text { 3.4; } \mathrm{SO}_{4}^{2-}, 3.5\end{array}$ & 21 \\
\hline $\begin{array}{l}\text { Butane-2,3-dione-bis(salicylhydrazonato)- } \\
\text { zinc(II) complex }\end{array}$ & $\begin{array}{l}\mathrm{Cl}^{-}, 4.1 ; \mathrm{Br}^{-}, 3.3 ; \mathrm{NO}_{3}^{-}, 3.0 ; \mathrm{SO}_{4}^{2-}, 4.1 ; \mathrm{NO}_{2}^{-}, 3.1 ; \mathrm{PO}_{4}^{3-}, 4.2 ; \text { acetate } \\
\text { 3.2 }, 4.2 ; \mathrm{HPO}_{4}{ }^{2-}, 4.0\end{array}$ & 23 \\
\hline Cadmium-Schiff's base complex & $\begin{array}{l}\text { Acetate }-4.6 ; \mathrm{ClO}_{4}^{-}, 2.04 ; \mathrm{NO}_{3}^{-}, 2.1 ; \text { salicylate } \\
\mathrm{Cl}^{-}, 2.01 ; \mathrm{Br}, 2.1\end{array}$ & 24 \\
\hline $\begin{array}{l}\text { Nickel(II)-1,4,8,11,15,18,22,25- } \\
\text { octabutoxyphthalocyanine }\end{array}$ & $\begin{array}{l}\mathrm{ClO}_{4}^{--}, 2.04 ; \mathrm{Cl}^{-}, 3.09 ; \mathrm{Br}^{-}, 2.6 ; \mathrm{I}^{-}, 2.39 ; \text { acetate } \\
\\
3.0\end{array}$ & 28 \\
\hline Nickel(II)-azamacrocycle complex & $\mathrm{Cl}^{-}, 3.3 ; \mathrm{Br}^{-}, 3.1 ; \mathrm{I}^{-}, 1.6 ; \mathrm{SO}_{4}^{2-}, 3.4 ; \mathrm{NO}_{2}^{-}, 2.5 ; \mathrm{NO}_{3}^{-}, 2.6 ; \mathrm{ClO}_{4}^{-}, 2.1 ;$ salicylate- ${ }^{-}, 2.8$ & 29 \\
\hline Cu-PADAP complex & $\begin{array}{l}\mathrm{I}^{-}, 2.7 ; \mathrm{NO}_{3}^{-}, 4.0 ; \mathrm{NO}_{2}^{-}, 3.7 ; \mathrm{ClO}_{4}^{-}, 2.2 ; \mathrm{Cl}^{-}, 4.2 ; \mathrm{PO}_{4}^{3-}, 4.3 ; \mathrm{Br}, 3.8 ; \text { acetate } \\
\text { salicylate } \\
-\end{array}$ & $\begin{array}{l}\text { This } \\
\text { work }\end{array}$ \\
\hline
\end{tabular}

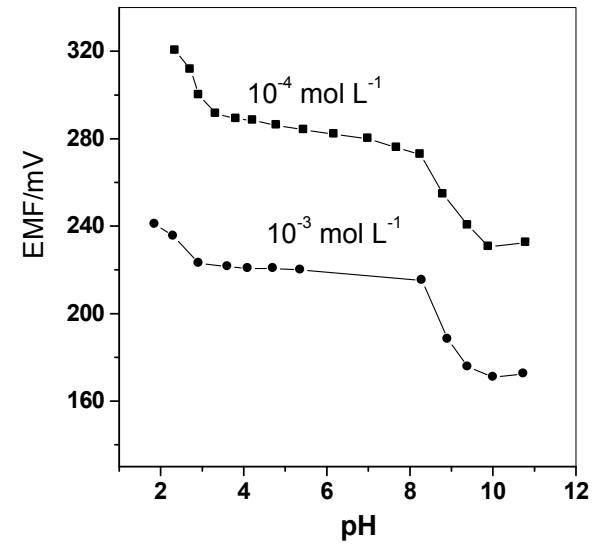

Fig. 4 Effect of the $\mathrm{pH}$ on the potentiometric response of a Cu-PADAP based membrane sensor.

\section{Flow-injection measurements}

A tubular-type detector incorporating a Cu-PADAP based membrane sensor was prepared and used under the hydrodynamic mode of operation for continuous $\mathrm{SCN}^{-}$quantification. A linear relationship between the $\mathrm{SCN}^{-}$concentrations and FIA signals was obtained over a concentration range of $1.0 \times 10^{-5}$ to $1.0 \times$ $10^{-2} \mathrm{~mol} \mathrm{~L}^{-1}$ using a $0.05 \mathrm{~mol} \mathrm{~L}^{-1}$ MES buffer, pH 5 (Fig. 5).

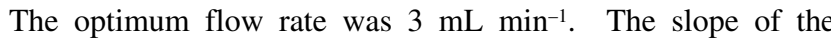
calibration plot was near-Nernstian $\left(-55.9 \pm 0.2 \mathrm{mV}\right.$ decade $\left.^{-1}\right)$. The lower limit of detection was $5.8 \times 10^{-6} \mathrm{~mol} \mathrm{~L}^{-1}$ and the sampling frequency was about 50 samples per hour.

Determination of thiocyanate in urine and saliva

A chemical test to distinguish smokers and non-smokers is important in many epidemiological studies. ${ }^{40}$ Experimental results have shown that the urinary and salivary $\mathrm{SCN}^{-}$ concentrations were higher for smokers than for non-smokers Thus, the adequate degree of $\mathrm{SCN}^{-}$selectivity exhibited by $\mathrm{Cu}$-PADAP based sensors make them potentially useful for monitoring the $\mathrm{SCN}^{-}$concentration levels in biological samples. The feasibility of using the proposed sensor to measure the thiocyanate concentration in human urine and saliva samples was examined. Samples were collected from various donors of age ranging from 25 to 65 years. Five donor groups (10 persons each) were tested: non-smokers (group I), smokers (1-5 cigarettes per day) (group II), smokers (6 - 10 cigarettes per

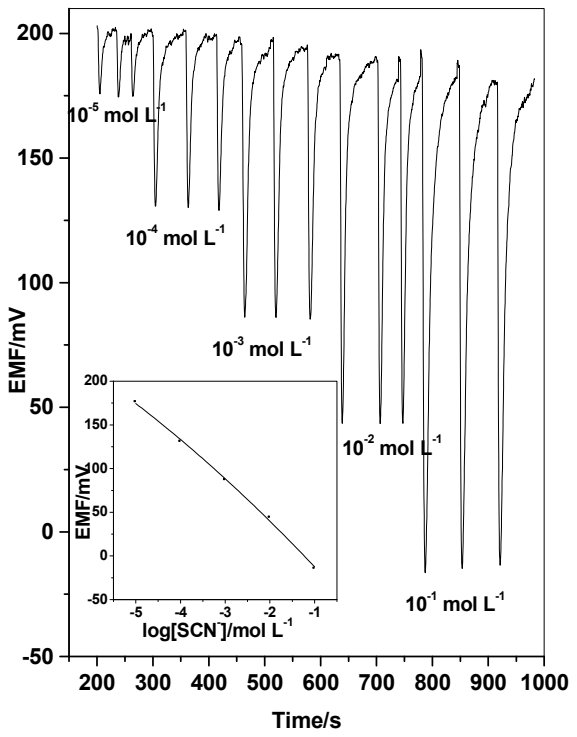

Fig. 5 Typical flow-injection potentiometric peaks obtained using the Cu-PADAP based membrane sensor towards thiocyanate.

day) (group III), and smokers (more than 20 cigarettes per day) (group IV). Table 4 indicates that the concentrations of saliva-SCN ${ }^{-}$and urine-SCN ${ }^{-}$in non cigarette smokers were $0.41-0.58$ and $0.09-0.18 \mathrm{mmol} \mathrm{L}^{-1}$, respectively. These results fairly agreed with data obtained by other authors using a spectrophotometric technique,,$^{41,42}$ and are in good agreement with results obtained by the reference spectrophotometric method (Table 4). The $F$-test showed no significant difference at the $95 \%$ confidence level between the mean and the variance of the potentiometric and spectrophotometric set of results. The calculated $F$-values $(n=5)$ were found to be in the range 0.9 - 5.1 compared with the tabulated value (6.39) at the $95 \%$ confidence limit.

\section{Determination of cyanide ions}

Determination of cyanide ion after its conversion to thiocyanate ion using the ammonium polysulfide treatment was investigated. Such a conversion is well-documented, and occurs according to the following reaction: ${ }^{43}$

$$
\left(\mathrm{NH}_{4}\right)_{2} \mathrm{~S}_{\mathrm{x}}+\mathrm{CN}^{-} \longrightarrow \mathrm{SCN}^{-}+\left(\mathrm{NH}_{4}\right)_{2} \mathrm{~S}_{\mathrm{x}-1} \text {. }
$$


Table 4 Potentiometric determination of thiocyanate in some saliva and urine samples using a thiocyanate PVC membrane sensor based on $\mathrm{Cu}-\mathrm{PADAP}$ and the standard spectrophotometric method ${ }^{41}$

\begin{tabular}{|c|c|c|c|c|c|c|}
\hline \multirow{3}{*}{$\begin{array}{l}\text { Test smoker } \\
\text { group }\end{array}$} & \multirow{2}{*}{\multicolumn{2}{|c|}{ Spectrophotometry ${ }^{41} / \mathrm{mmol} \mathrm{L}^{-1}$}} & \multicolumn{4}{|c|}{ Potentiometry/mmol L ${ }^{-1}$} \\
\hline & & & \multicolumn{2}{|c|}{ Batch } & \multicolumn{2}{|c|}{ FIA } \\
\hline & Saliva & Urine & Saliva & Urine & Saliva & Urine \\
\hline (I) & $(0.41-0.51) \pm 0.2$ & $(0.10-0.15) \pm 0.1$ & $(0.40-0.58) \pm 0.1$ & $(0.09-0.17) \pm 0.2$ & $(0.42-0.55) \pm 0.3$ & $(0.11-0.18) \pm 0.2$ \\
\hline (II) & $(0.61-0.72) \pm 0.3$ & $(0.31-0.35) \pm 0.3$ & $(0.60-0.75) \pm 0.2$ & $(0.29-0.32) \pm 0.1$ & $(0.59-0.69) \pm 0.1$ & $(0.30-0.35) \pm 0.4$ \\
\hline (III) & $(1.97-2.10) \pm 0.1$ & $(1.51-1.62) \pm 0.2$ & $(1.89-2.20) \pm 0.4$ & $(1.50-1.61) \pm 0.4$ & $(1.93-2.18) \pm 0.3$ & $(1.49-1.62) \pm 0.3$ \\
\hline (IV) & $(3.91-4.21) \pm 0.3$ & $(2.35-2.46) \pm 0.4$ & $(4.40-4.71) \pm 0.2$ & $(2.51-2.72) \pm 0.3$ & $(4.45-4.71) \pm 0.5$ & $(2.44-2.53) \pm 0.2$ \\
\hline
\end{tabular}
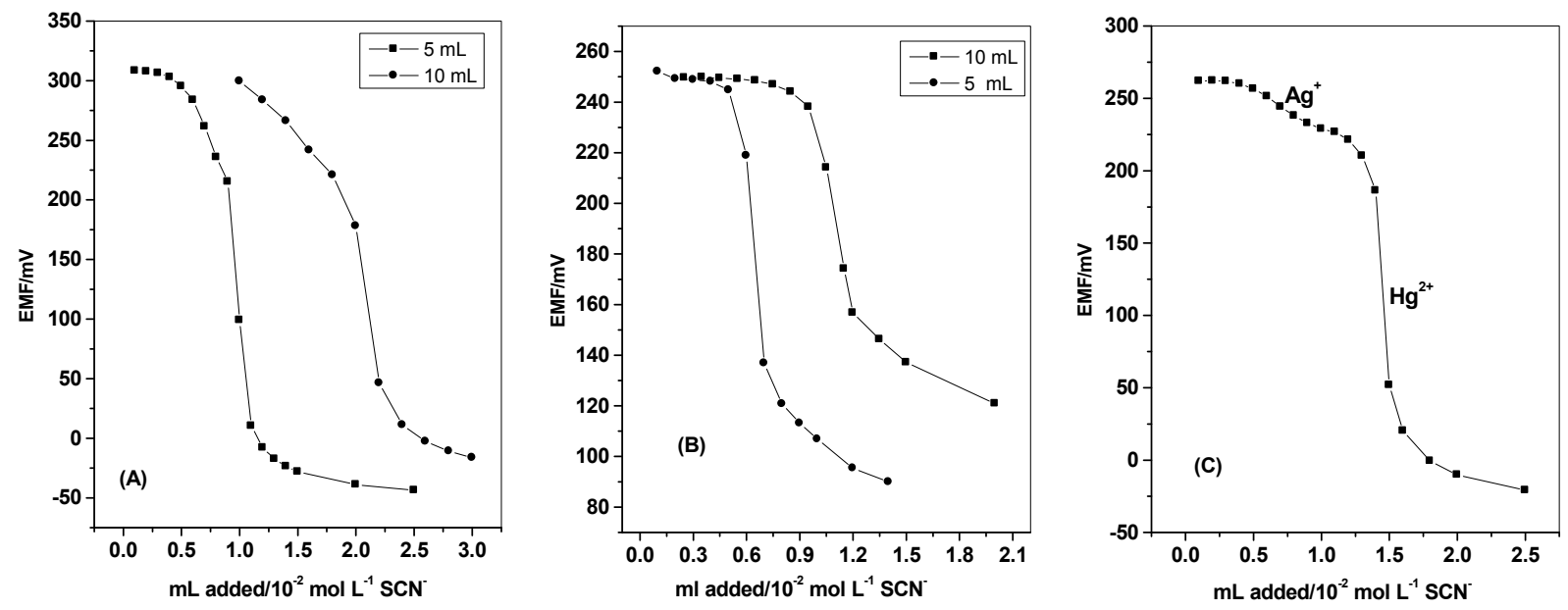

Fig. 6 Typical potentiometric titration plots using the $\mathrm{Cu}$-PADAP based membrane sensor and $1.0 \times$ $10^{-2} \mathrm{~mol} \mathrm{~L}-1$ SCN titrant. (A) 5 (ם) and $10(\bigcirc) \mathrm{mL}$ of $1.0 \times 10^{-3} \mathrm{~mol} \mathrm{~L}^{-1} \mathrm{Hg}^{2+}$ solutions, (B) 5 (O) and 10 (ם) $\mathrm{mL}$ of $1.0 \times 10^{-3} \mathrm{~mol} \mathrm{~L}-1 \mathrm{Ag}^{+}$solutions, (C) a mixture of $5 \mathrm{~mL}+5 \mathrm{~mL}$ of $1.0 \times 10^{-3} \mathrm{~mol} \mathrm{~L}^{-1} \mathrm{Hg}^{2+}$ and $\mathrm{Ag}^{+}$solutions.

A linear calibration curve for $\mathrm{CN}^{-}$ions $\left(1.0 \times 10^{-5}-1.0 \times 10^{-2}\right.$ mol L $\mathrm{L}^{-1}$ ) after conversion into $\mathrm{SCN}^{-}$by a treatment with ammonium polysulfide solution, followed by monitoring using a Cu-PADAP based membrane sensor was obtained. The method was used for the potentiometric determination of free cyanide ions in industrial waste-water samples obtained from an electroplating factory. The obtained results $\left(55-105 \mathrm{mg} \mathrm{L}^{-1}\right)$ agreed well with data obtained using the solid state cyanide ionselective electrode (Table 5).

\section{Potentiometric titration of metal ions}

The thiocyanate sensor based on Cu-PADAP was used as an indicator electrode for monitoring the titration of silver and mercury metal ions and their binary mixtures using a standard thiocyanate solution. The obtained titration curves showed sharp inflection breaks $(\sim 100 \mathrm{mV})$ at 1:1 and 2:1 reactions for $\mathrm{SCN}^{-} / \mathrm{Ag}^{+}$and $\mathrm{SCN}^{-} / \mathrm{Hg}^{2+}$, respectively. For the titration of a binary mixture $\left(\mathrm{Ag}^{+}+\mathrm{Hg}^{2+}\right)$, two sharp successive inflection breaks at the equivalent points of both metals were obtained. Typical potentiometric titration curves are shown in Fig. 6.

\section{Conclusions}

A Cu-PADAP based PVC membrane sensor was prepared and used for the thiocyanate measurement. The sensor was utilized for manual and FIA monitoring of $\mathrm{SCN}^{-}$. Under the static mode
Table 5 Potentiometric determination of cyanide in electroplating baths after conversion into thiocyanate using a thiocyanate PVC membrane sensor based on Cu-PADAP

\begin{tabular}{ccc}
\hline \multirow{2}{*}{ Sample } & \multicolumn{2}{c}{ Cyanide content $/ \mathrm{mg} \mathrm{L}^{-1 \mathrm{a}}$} \\
\cline { 2 - 3 } & Cu-PADAP sensor & Solid state cyanide sensor \\
\hline \multirow{2}{*}{1} & $55.9 \pm 0.3$ & $61.2 \pm 0.6$ \\
2 & $98.2 \pm 0.6$ & $103.1 \pm 0.4$ \\
3 & $105.4 \pm 0.8$ & $114.2 \pm 0.6$ \\
\hline
\end{tabular}

a. Average of 5 measurements.

of operation, the sensor displayed high selectivity in the presence of many anionic species, a wide dynamic response range $(7.0 \times$ $10^{-6}$ to $\left.1.0 \times 10^{-2} \mathrm{~mol} \mathrm{~L}^{-1}\right)$, a low detection limit $(5.6 \times$

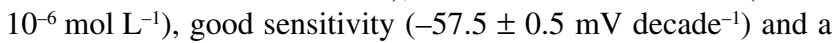
rapid response $(10 \mathrm{~s})$. Under the hydrodynamic mode of operation, the sensor exhibited a near-Nernstian slope of -55.9 $\pm 0.1 \mathrm{mV}$ decade $^{-1}$ over a concentration range of $1.0 \times 10^{-5}$ $1.0 \times 10^{-2} \mathrm{~mol} \mathrm{~L}^{-1} \mathrm{SCN}^{-}$. These characteristics enabled accurate measurements of as low as $0.2 \mu \mathrm{g} \mathrm{mL}^{-1}$ thiocyanate in the saliva and urine of cigarette smokers and non-smokers. Cyanide after conversion into thiocyanate and some metal ions were also accurately measured. 


\section{References}

1. J. C. Wilmot, L. Solujic, E. B. Milosavljevic, J. L. Hendrix, and W. S. Rader, Analyst, 1996, 121, 799.

2. P. M. Maliszewski and H. E. Bass, J. Appl. Physiol., 1955, 8, 289.

3. Z. Guien, L. Bin, F. Jing, and F. Suling, Talanta, 1997, 44 , 1141.

4. J. F. van Staden and A. Botha, Anal. Chim. Acta, 2000, 403, 279.

5. B. Gong and G. Gong, Anal. Chim. Acta, 1999, 394, 171.

6. T. Kato, Mol. Phys., 1987, 60, 1072.

7. Y. Tanaka, N. Naruishi, H. Fukuya, J. Sakata, K. Saito, and S. Wakida, J. Chromatogr., A, 2004, 1051, 193.

8. Z. M. Fu, S. H. Ni, and Z. H. Pang, Fenxi Shiyanshi, 1993, 12,85 .

9. Y. Michigami, K. Fujii, K. Ueda, and Y. Yamamoto, Analyst, 1992, 117, 1855.

10. L. Li, A. Wang, P. He, and Y. Fang, Fresenius J. Anal. Chem., 2000, 367, 649.

11. J. A. Cox, T. Gray, and K. R. Kulkarni, Anal. Chem., 1988, $60,1710$.

12. K. Sollner and G. M. Shean, J. Am. Chem. Soc., 1964, 86, 1901.

13. D. M. Pranitis, M. Telting-Diaz, and M. E. Meyerhoff, Crit. Rev. Anal. Chem., 1992, 23, 163.

14. P. Schulthess, D. Ammann, W. Simon, C. Caderas, R. Stepanek, and B. Krautler, Helv. Chim. Acta, 1984, 67, 1026.

15. N. A. Chaniotakis, A. M. Chasser, M. E. Meyerhoff, and J. T. Groves, Anal. Chem., 1988, 60, 185.

16. A. Hodinar and A. Jyo, Anal. Chem., 1989, 61, 1169.

17. H. Abe and E. Kokufuta, Bull. Chem. Soc. Jpn., 1990, 63, 1360.

18. N. A. Chaniotakis, S. B. Park, and M. E. Meyerhoff, Anal. Chem., 1989, 61, 566.

19. F. Z. El-Aamrani, J. Garcia-Raurich, A. Sastre, L. Beyer, and A. Florido, Anal. Chim. Acta, 1999, 402, 129.

20. M. M. Ardakani, A. A. Ensafi, M. S. Niasari, and S. M. Chakooki, Anal. Chim. Acta, 2002, 462, 25.

21. X. Huang, Y. Chai, R. Yuan, X. Wang, and Q. Li, Anal. Sci., 2004, 20, 1185.

22. M. Rothmaier, U. Schaller, W. E. Morf, and E. Pretsch, Anal. Chim. Acta, 1996, 327, 17.
23. M. M. Ardakani, A. Sadeghi, and M. S. Niasari, Talanta, 2005, 66, 837.

24. M. R. Ganjali, T. Poursaberi, F. Basiripour, M. S. Niassari, M. Yousefi, and M. Shamsipur, Fresenius J. Anal. Chem., 2001, 370, 1091 .

25. Z. Q. Li, Z. Y. Wu, R. Yuan, M. Ying, G. L. Shen, and R. G. Yu, Electrochim. Acta, 1999, 44, 2543.

26. S. S. M. Hassan, W. H. Mahmoud, A. S. H. Elgazwy, and N. M. Badawy, Electroanalysis, 2006, 18, 2070

27. M. S. Messick, S. K. Krishnan, M. K. Hulvey, and E. D. Steinle, Anal. Chim. Acta, 2005, 539, 223.

28. H. A. Zamani, F. Malekzadegan, and M. R. Gaiyali, Anal. Chim. Acta, 2006, 555, 336.

29. M. R. Ganjoli, M. Youusefi, M. Javanbakht, T. Poursaberi, M. S. Niasari, L. H. Babaei, E. Latifi, and M. Shamsipur, Anal. Sci., 2002, 18, 887.

30. S. Erden, A. Demirel, S. Memon, M. Yilmaz, E. Canel, and E. Kilic, Sens. Actuators, B, 2006, 113, 290.

31. S. Oszwaldowski, J. Witowska, and M. Jarosz, J. Mass Spectrom., 2001, 36, 1230.

32. S. S. M. Hassan, M. M. Amer, S. A. Abd El-Fatah, and A. M. El-Kosasy, Anal. Chim. Acta, 1998, 363, 81.

33. S. S. M. Hassan, M. H. Abou Ghalia, A.-G. E. Amr, and A. H. K. Mohamed, Anal. Chim. Acta, 2003, 482, 9.

34. S. S. M. Hassan, I. H. Badr, and H. S. M. Abd-Rabboh, Mikrochim. Acta, 2004, 144, 363.

35. D. Nonova and K. Stoyanov, Mikrochim. Acta, 1984, I, 143.

36. S. S. M. Hassan, S. A. Marei, I. H. Badr, and H. A. Arida, Electroanalysis, 2000, 12, 1312.

37. T. S. Ma and S. S. M. Hassan, "Organic Analysis Using Ion Selective Electrodes", 1982, Vols. I and II, Academic Press, London.

38. E. Bakker, E. Pretsch, and P. Bühlmann, Anal. Chem., 2000, 72, 1127.

39. E. Bakker, E. Malinowska, R. D. Schiller, and M. Meyerhoff, Talanta, 1994, 41, 881.

40. S. Amemiya, P. Buhlmann, E. Pretsh, B. Bnsterholz, and Y. Umezawa, Anal. Chem., 2000, 72, 1618.

41. W. C. Butts, M. Kuehneman, and G. M. Widdowson, Clin. Chem., 1974, 20, 1344.

42. M. Lahti, J. Vilpo, and J. Hovinen, J. Chem. Educ., 1999, 76, 1281

43. B. Demirata, R. Apak, H. Afsar, and I. Tor, J. AOAC, 2002, $85,971$. 